\title{
Monitoring AND AcCountabiLity IN \\ Professional DeVelopment of Teachers in \\ RURAL PAKISTAN
}

\author{
Ali Nawab ${ }^{a}$ \\ Sukkur IBA University
}

\begin{abstract}
Both experience and studies suggest that teachers in rural Pakistan either show reduced interest towards Professional Development (PD) or if they avail limited PD opportunities, they hardly bring any significant changes in their instructional practices. One of the assumptions in this regard, although not proved empirically, is that the system where teachers work lack monitoring and accountability mechanism. In this background, this research aimed to understand the monitoring and accountability system influencing teachers' participation in PD. Using focused interview procedure, data were collected from the key stakeholders namely teachers, school leaders, officials of education department and representatives of PD provider organisations. It was found that officials from education department extend surprisingly limited monitoring support to the teachers in schools. Moreover, the system lacks any recognition or reward for PD. Involvement in PD makes no difference in the career of a teacher. Consequently, teachers show reduced interest towards $P D$. The research suggests that to enhance teachers' participation in $P D$, the system should introduce a system of appraisal where teachers are made accountable for $P D$, and rewarded based on the changes they bring in their practices through availing PD opportunities.
\end{abstract}

Keywords: Accountability, monitoring, professional development, rural Pakistan

\section{Introduction}

The importance of Professional Development (PD) of teachers in student achievement has been well established in educational literature (Darling-Hammond, Wei, Andree, Richardson, \& Orphanos, 2009). Since students of today accessing education are diverse in their backgrounds and abilities, only a well-trained and highly professional teacher tends to succeed in providing quality learning environment to those diversified students (Lohman, 2000). The quality of the teacher, on the other hand, depends on the quality of PD he or she undergoes. As Guskey (2000, p. 4) contends, "one constant finding in the research literature is that notable improvements in education almost never take place in the absence of professional development". Consequently, PD has been the major focus of many reform initiatives to improve the standard of education (Dinham, 2007; Easton, 2008).

In Pakistan, PD of teachers has been a provincial responsibility, and all the four provinces have their own training institutes. A report of National Education Management Information System (2017) indicates that currently, 209 teacher training institutions operate in the public sector offering a variety of pre-service as well as in-service programmes. The Certificate in Teaching (CT) and Primary Teaching Certificate (PTC) programmes have been the dominant models of initial teacher education; preparing teachers for secondary and primary levels respectively. Owing to a growing criticism on these programmes for their lack of quality and relevance (Ali, 2011; UNESCO, 2011), a shift has been introduced in the pre-service training of teachers funded and managed by United States Agency for International Development (USAID). Under this programme, replacing the traditional CT and PTC, USAID has introduced a four-year Bachelor of Education (BEd) and a two-year Associate Degree in

a Correspondence can be directed to: ali.nawab@iba-suk.edu.pk 
Education (ADE) with an entry requirement of 12 years of schooling. Starting in 2011, the degree is being offered at around 16 teaching institutions in Pakistan.

Moreover, a huge number of non-state actors such as non-governmental organisations (NGOs) and civil society institutions supplement the government efforts mainly in the provision of in-service PD programmes. Most of these agencies use the conventional external workshop ranging from a few hours to several weeks courses. The projects also vary regarding the aims and content, which are largely determined by the intentions and priorities of individual donors (USAID, 2006). A major concern shown in previous studies is that no visible difference was observed in the classroom practices of the teachers who attended the in-service programmes (Mohammed \& Harlech-Jones, 2008; Nawab, 2017). The key reasons restricting the implementation of new practices are found to be the lack of administrative, professional and emotional support for teachers to assist them to translate theory into practice (Hussain \& Ali, 2010; Rizvi \& Elliott, 2007). Although, empirical evidence lack, follow-up visits to in-service trainees suggest that teachers of private schools attending the PD programmes are more likely to implement their learning compared with their counterparts in the public schools. Perhaps the major reason which is also supported by studies in the developing countries is that unlike teachers in the public schools, private school teachers are more accountable to the school owners as well as to the community (Mbiti, 2016). However, in the context of Pakistan, academics have given surprisingly little attention on how monitoring and accountability affect teachers' involvement in PD activities. In this background, the purpose of this research was to explore the monitoring and accountability system in relation to PD of teachers in rural Pakistan with the aim to raise this important aspect of quality education to the attention of policy makers, PD providers and researchers and to provoke a discussion and further research on the topic. The outcome may contribute to enhanced monitoring and accountability mechanism in the field of teacher PD which may lead to improved teaching and learning practices in schools ultimately resulting in enhanced learning outcomes for students in the rural context of Pakistan.

\section{Monitoring and Accountability in Professional Development}

In educational literature, a close association has been shown between the academic achievement of students and the quality of teachers (Guskey, 2002; Darling-Hammond, 2004). Teachers' quality, on the other hand, is said to be linked with the learning opportunities they avail (Fullan, 1993). Given this logic, if a teacher enhances his/her teaching practices availing quality learning opportunities, it is more likely for him/her to enhance academic achievement for students. However, each and every teacher may not avail quality learning experiences. Even if teachers avail such opportunities, they need not necessarily implement their learning. One of the many conditions which drive teachers to learn and to improve their practice on an ongoing basis is said to be the presence of accountability (Hattie, 2003). If teachers' practices are constantly monitored aiming to bring changes in their practice, they tend to look for and avail any learning opportunity. Consequently, improved teaching practices and enhanced student achievement can be possible in an environment of rigorous monitoring and accountability (Reeves, 2005).

Accountability in PD of teachers is said to be an integral part of the very design of PD (KinnucanWelsch, Rosemary, \& Grogan, 2006). While designing PD for teachers, the planners need to consider accountability as a significant principle and to formulate strategies to make teachers accountable in brining changes in their practices. Making accountability as an integral part of the design also suggests that the entire process of a PD programme, from its design to implementation, should be systematically monitored using the lens of accountability. Presenting a framework for PD in an accountability context, Hochberg and Desimone (2010) suggest considering those features of PD which impact teachers' practices in a positive way. For these authors, the primary goal in the accountability model of PD is achieving particular standards for all students and aligning instruction with those standards.

Thus, as the accountability model of PD suggests, standard for students and instruction to achieve those standards are the main focus for accountability. There are three major actors who 
make teachers accountable in this regard. The first category is that of PD providers who extend or supposed to extend monitoring and follow-up support to teachers to make them implement their learning acquired from PD programmes (Ramatlapana, 2009). Next are the immediate supervisors who evaluate teachers in relation to the standards set for students and the instruction to achieve those standards (Wells, 2014). Ideally, such evaluation of teachers by their supervisors can be an ongoing feature of schools (Darling-Hammond, 2017). Teachers should be constantly supported and evaluated especially in relation to the standards set for them and for their students. On the basis of their performance in relation to the set standards as well as their commitment to change and improvement, teachers are recognised and rewarded which result in further innovative behaviours and practices (Darling-Hammond, 2000; Fullan, 2007; Hargreaves, 2003). Such transparent accountability mechanism also helps to address any inequalities in the system which, if unresolved, may lead to conflicts among staff (Smith, 2014).

Thirdly, although the PD providers and supervisors hold the major responsibility of monitoring teachers and making them accountable, nothing will be as powerful in bringing change in educational practices as teachers' own attitude to embrace accountability and to examine their practices in relation to the standard set for students (Reeves, 2005). Developing teachers having such attitude is perhaps the biggest challenge. Research shows that teachers in high achieving schools embrace more internal accountability mainly owing to the school principals who involve them in setting educational goals and empower them to achieve those goals (Yi \& Kim, 2019). It suggests that teachers are more likely to embrace accountability when they are empowered and trusted. Consequently, it is the environment mainly created by the system and school leaders that determine the extent to which teachers are made accountable.

When we relate the existing knowledge on monitoring and accountability in PD to the existing situation in Pakistan, we find a mismatch between the ways these concepts are portrayed in educational literature and practiced in this part of the world. At policy level, there are optimistic intensions with regard to the provision and evaluation of PD. The National Education Policy of 2009, for example, reads that, "All teachers shall have opportunities for professional development through a programme organised on a three-year cyclic basis. Progress in career shall be linked to such professional development" (Ministry of Education, 2009a, p. 38). However, the stated policies in Pakistan have usually remained a 'wish list' or merely rhetoric, barely translated into practice. Although it may be true that the apparent barrier to monitor the progress of teachers through a systematic appraisal system is the lack of staff and resources (USAID, 2006), it is important not to overlook the importance of a comprehensive and clear framework to monitor teachers and to make them accountable (Ali, 2011). Teachers in public schools, for example, are still appraised using the decades old ACR (Annual Confidential Report). The ACR is a summative evaluation conducted by the school leadership at the end of the year and kept confidential from teachers restricting the opportunities to identify and address their areas for improvement. Consequently, the appraisal system not only lacks a potential to enhance the quality of teachers (Hyun \& Sajjad, 2018; G. Khan, Khan, Hussain, \& Shaheen, 2017) but also results in their demotivation (Nadeem, Arif, \& Asghar, 2019). Although, government officials in the public sector pay occasional visits to schools to monitor compliance with standards, their focus is mainly administrative such as enrolment, attendance and so on (Mbiti, 2016). Even if there is some academic accountability, it is about test scores.

Evidence suggests, however, that compared with public schools, private schools in Pakistan apply strict appraisal system consequently leading to improved performance of teachers (Agha, Alwi, \& Shaiq, 2020; Hyun \& Sajjad, 2018; Khan, Chandio, \& Farooqi, 2014). The classroom observations by the school principals, evaluation of teachers' plans, planning before academic sessions and students' report cards were the examples of formative evaluation carried out by the school principals that were not evident in the public sector schools. Teachers are then awarded or reprimanded based on their performance. It is the fear of being fired that teachers in private school perform better (Nadeem et al., 2019). Otherwise, teachers do not see any connection between appraisal and their PD (Khan, 2015). 
Although, we have some knowledge on monitoring and accountability in the context of Pakistan, it has two major gaps. Firstly, the nature of monitoring and accountability in relation to PD of teachers has remained unattended so far. While we know many other factors influencing PD of teachers in Pakistan, we do not know what monitoring and accountability mechanisms are in place to appraise teachers for their PD and how these procedures influences their involvement in PD activities. Secondly, the existing limited knowledge also comes from the urban context of Pakistan. Rural contexts characterized by the low achievement of students require greater attention with regard to quality teachers given that the student achievement is associated with the quality of teachers (Darling-Hammond, 2004). However, we do not know how teachers in the rural context of Pakistan are monitored, supported and made answerable in relation to PD. Understanding this scenario may help educational reformers and PD providers to focus on those areas which hinder teachers' participation in PD and the implementation of their learning after attending PD programmes. Students of rural context who have otherwise remained constrained by remoteness would be the ultimate beneficiaries.

\section{Research Method}

Aimed to understand the nature of monitoring and accountability in relation to PD of teachers in rural Pakistan, this research used a qualitative approach which allows a researcher to personally interact with the participants and to listen to them in their natural setting (Bogdan \& Biklen, 1998). The setting for the research was District Chitral, a remote rural region of Khyber Pakhtunkhwa province, Pakistan. In this region, participants in a reasonably large number were taken from a variety of relevant stakeholders such as teachers, school leaders, government education officials and PD providers. Teachers teaching at secondary level were preferred because, as District Education Office records showed, teachers at this level avail greater PD opportunities compared with their junior school counterparts. Out of the secondary level teachers, the ones who availed PD opportunity during the last three years were considered with the assumption that they could provide more relevant data on monitoring and accountability in the system. Out of 1159 teachers working in the High Schools in the research region (Government of Khyber Pakhtunkhwa, n.d.), as per the record of District Education Office, 88 teachers had availed in-service PD opportunities during the last three years. Using random sampling procedure (Fraenkel \& Wallen, 2009), invitation letters were sent to 50 teachers, 32 of them agreed to participate in the research. Similarly, out of 38 school leaders who had availed PD during the last three years, 12 were selected using random sampling procedure. Four officials from the Education Department and five PD provider representatives were recruited through purposive sampling procedure (Bloor, Frankland, Thomas \& Robson 2001) aimed to consult with those individuals having the responsibility of working with schools, teachers and school leaders.

Focus group interview procedure was used to stimulate respondents to recall specific events and to articulate their views through exposing them to the experiences of others (Rubin \& Rubin, 2011). Similarly, to overcome any issue of status or power (Bloor et al, 2001), separate groups were formed of PD providers, education officials, school leaders and teachers. Each group was interviewed twice, each interview lasting 50 to 90 minutes.

The research used certain measures to ensure authenticity and transparency in the data collection and their subsequent interpretation as suggested by the prominent qualitative research theorists (Guba \& Lincolin, 2000; Patton, 2002). The first measure in this regard included recruiting assumedly more informed participants, those having experience of PD. Secondly, data were collected from individuals representing the field at multiple levels, such as, teachers, school leaders, education officials and PD providers. Thirdly, the data were constantly compared within and between groups to draw authentic conclusions. Finally, using the concept of reflexivity (Clarke, 2006), the researcher critically looked at any influences that might affect the collection and interpretation of data.

The data were collected and analyzed simultaneously. The focus group interviews conducted in the mother tongue of the participants were first transcribed, then translated and coded. Next, 
frequently occurring patterns were identified out of the coded data. The patterns were then organised under the two major themes, namely, monitoring and accountability.

\section{Findings}

The findings under the two major themes, namely, monitoring and accountability are presented and interpreted below.

\section{Monitoring}

Monitoring was found to be a significant contextual factor influencing the quality of PD in the research region. Interviews with the stakeholders revealed that the public and private sectors have their unique monitoring systems. Private schools are mostly owned and managed by individuals who either work as principals of their respective schools or employ other individuals to lead the school as a principal. Thus, in the private sector, monitoring of school practices is the responsibility of school leaders. Apart from the school leaders, private schools lack any other formal monitoring body. However, there is another type of private sector in the research region called the Aga Khan Schools. Administered by the Aga Khan Education Service (AKES), a unit of the Aga Khan Development Network (AKDN) ${ }^{1}$, these schools usually operate in remote areas of the region where children lack access to public or other private schools. Unlike the other private schools, AKES has a monitoring system where a team of professionals supervises teaching and learning processes in the Aga Khan Schools.

In the public sector, District Education Officer (DEO), Sub-Divisional Education Officers (SDEOs) and Assistant District Education Officers (ADEOs) are responsible for monitoring the day to day routines and activities of schools. The quality of monitoring extended by these officials regarding PD of teachers was, however, debatable among the research participants. Most of the teachers representing the public sector reported that officials from education department seldom visit their schools. Even if they come to their classroom, the time spent is very limited. Teachers, especially the ones who attend PD, expect enhanced support from district education officials. Shafiq ${ }^{2}$ a teacher from the public sector, reported that:

DEO visiting schools is very uncommon. I have not seen him ever entering my classroom. SDEO and ADEOs may occasionally visit class but they do not observe teaching. They may just enter the class and ask students some questions. They do not ask us what we learnt from training and what we need to implement and what challenges we face in the process of implementation.

This view represents a general concern of teachers from the public sector that officials rarely monitor their practices once they return attending PD programmes. Although SDEO and ADEOs occasionally visit teachers, they demonstrate little concern regarding which teachers attended PD, what they learnt, and to what extent they implement their new understandings. Teachers expect more support from their respective officials in addressing their emerging issues during implementation given that PD providers are largely unable to extend such support. However, the occasional visits of these officials and their limited stay in schools were less likely to address the issues of particularly those teachers who were struggling with the new practices acquired through attending PD programmes.

Similarly, school leaders representing the public sector also expressed their concern regarding the nature of monitoring system in the public schools. They were of the view that just providing teachers with PD opportunities was not enough unless they were systematically monitored to implement their learning. Arifa, a school leader from the public sector, stated that:

More importantly, teachers should strictly be monitored to make them implement the ideas which they bring back from the external trainings. Supervisors should identify the challenges teachers face or the reason behind the lack of implementation. Unless teachers are properly 
monitored by the officials from the system, teachers will never bother to do something innovative or to improve their practices. Monitoring is the lacking element in our system.

This lack of proper monitoring support to teachers is not simply a matter of omission; its lack was also recognised by ADEOs who provided some insight as to why it might not occur. The major challenge in this regard was the inadequate provision of human resources. It was revealed that there were insufficient ADEOs to look after the number of schools involved. As Afzal reported:

I have 12 days in a month for school visits and there are 275 schools under my jurisdiction. I visit each school once in a year. There will be quite a few schools that I visit twice in a year. When I have to visit three or four schools in one day, I have very limited time for classroom observation or to discuss with teachers their issues and needs.

This excerpt suggests that the main reason behind the reduced monitoring support to the teachers is the heavy workload of the education officials. One ADEO extending quality monitoring support to teachers of 275 schools is almost impracticable. Ideally, an ADEO should observe lesson of each teacher and extend required support. In the given condition, it is unsurprising if the ADEO fails to reach every teacher in his/her jurisdiction during the entire year. Therefore, a one-off visit, or at most two visits, of ADEOs to schools in a year could hardly be sufficient to influence teachers' practices. Research from other developing countries such as Tanzania (Mbiti, 2016) suggests that teachers are unlikely to change their practices when they receive limited monitoring support from the education officials. It has also been argued that instead of brief visits by supervisors, bringing improvement in practices of teachers requires consistent monitoring and evaluation of teachers (Darling-Hammond \& McLaughlin, 2011). Such consistent monitoring of teaching practices, however, was a component severely lacking in schools of the research region ultimately leading to less impact of PD on practices of teachers.

\section{Accountability}

Lack of monitoring by education officials and PD providers resulted in a lack of accountability. This not only hindered translation of learning from training to classroom but also influenced teachers' involvement in PD activities. Participants collectively believed that the public sector lacked a mechanism to make teachers accountable to implement their learning and to recognise, reward or reprimand them on their growth and performance. It was also revealed that the involvement in PD or otherwise did not make a difference in the career and incentives for teachers. All the teachers were treated equally irrespective of their attitude towards and involvement in PD. There was no actual pressure upon teachers to improve their practices. A representative quote is taken from Nazia, an ADEO from the public sector, who revealed that:

Whether a teacher implements his/her learning or not, whether they improve their practices or not, no one is there to ask them. If someone attends PD programmes, there is no appreciation. Attending PD programmes or improving practices doesn't make a difference in the career of a teacher.

Teachers' commitment towards improvement is achieved through incentives based on their performance (Fullan, 2007). When the system lacks accountability and reward mechanisms, it is disheartening for those teachers who are committed to improving their practices. Sardar, a school leader from the public sector, had similar view that when a high performing teacher and his low performing counterpart are treated equally, teachers hesitate to take part in PD activities.

Coupled with appreciating teachers for their growth and performance, their commitment toward PD and implementation of their learning might be achieved through considering their capability for promotion. Participants reported, however, that teachers in the public sector were promoted to senior positions based on their seniority without considering their capacity and professional growth. Afzal, an SDEO, remarked that: 
A teacher feels that no one can stop my promotion if I am the most senior. Such policy is required that if a teacher develops himself and brings improvement in his/her practices, he/ she will be promoted. If performance is rewarded, it will force teachers to develop themselves. Otherwise, teachers are not willing to improve their practices.

Aligned with the earlier studies (for example, Behlol, Dad, \& Raja, 2014; Siddiqui, 2016), promotion is largely unrelated to the actual performance of teachers in low-income developing countries of Asia including Pakistan. The performance of teachers, as revealed by the participants, was evaluated through a process called Annual Confidential Report (ACR). Participants in this study, however, reported several flaws in this system. Firstly, the existing ACR system lacked any weighting for PD of teachers. Secondly, ACRs were written confidentially by school leadership without taking teachers into confidence. Based on such system, teachers did not know their strengths and areas for improvement. In this sense, the appraisal system lacked an 'improvement function' (OECD, 2013), a function of appraisal that helps teachers improve their practices through identifying their strengths and weaknesses.

Participants representing the private sector reported a relatively improved picture of accountability in the private schools. It was revealed that student achievement in the private schools was relatively high compared to student achievement in the public sector schools. Participants reported that one of the primary reasons for better performance of the private schools was the accountability system. Support for this view comes from earlier reports suggesting that better learning outcomes for students in the private schools of North-Western Pakistan are owing to the higher degree of systematic management control over teachers' performance (Bennell, 2004). Participants revealed that compared with the public sector, there was no job security in the private system where teachers were retained only if they performed well. It was also revealed that in the private sector, the local community put pressure on school leadership and school leadership in return put pressure upon teachers. Irfan, a private school leader, revealed that:

There is competition among private sector schools. Since parents pay for their children, they also want good results. To attract students, private schools have to prove their worth. It will be possible if teachers work hard. I want to see output from teachers. Otherwise, they will be replaced. Teachers show more dedication because they know the consequences.

This view of school leadership supports the earlier findings from Pakistan that in the private schools teachers work hard as they are held accountable by parents, and there is a risk of losing students to other schools in case of poor performance (Andrabi, Das, \& Khwaja, 2008). In addition, school leaders hold authority to hire and fire teachers, which makes them more conscious of their practices and growth (Nadeem et al., 2019). On the contrary, when teachers are recruited by a central authority as in case of public schools, it becomes difficult for parents and school leaders to make them accountable (Mbiti, 2016).

Some of the participants also referred to the accountability system in the Aga Khan Schools. Inayat, a representative of PD providers, stated that in the Aga Khan Schools, the implementation of PD learning is prioritised because AKES staff systematically appraise their teachers. Teachers who develop themselves, bring innovation in their teaching and apply their learning in classroom, score higher in the appraisal. Inayat further revealed that through the appraisal system at the Aga Khan Schools, the improvement areas of teachers were identified and addressed. Consequently, the model serves both accountability and improvement functions (OECD, 2013). These functions of appraisal have also been documented through research studies conducted on appraisal system in the Aga Khan Schools in Pakistan (Khan, 2015).

The appraisal system, however, is carried out only at the AKES system. Such a system was lacking in other private sector schools in the research region. Although school leaders from the private sector showed growing pressure on the schools and teachers from the community, teachers representing 
the private schools reported the lack of any mechanism to hold teachers accountable for engagement with PD and application of their learning into practice. Razia, a private school teacher, reported that:

Our management does not encourage us to attend PD. Often they hesitate to send us for external PD saying that there is no one to engage our classes. Even if we attend PD, school management never asks us about our learning and what we need to implement. I had attended a seven-day workshop with the Star Institute. No one asked me whether I benefited from that course or not. The management needs to ask teachers before and after the course what she needed and what the improvement in her practices was after attending the training.

While the private schools exert pressure on teachers to produce better student results, as the above excerpt suggests, no systematic mechanism was in place to evaluate teachers and to make them accountable for learning and implementation. The data suggests that the private schools do want improved results for students, however, they lack realisation that student achievement could be enhanced through developing the capacity of teachers. Teachers reported that they were not encouraged to attend PD. Even if teachers attended PD on their own interest, there was no pressure on them or support to implement their learning. Attending PD appears to be a mere compliance. Ideally, once a new idea enters an organisation there should be structures and cultures to cascade the learning and to make it part of the organisational capacity (Lange, 2014). However, schools in this region lacked a mechanism to support implementation of new learning and to cascade it to other teachers.

\section{Discussion and Implications}

A critical analysis of data presented above suggests that the lack of proper monitoring and accountability is a significant factor in the research region that, similarly to other developing countries (World Bank, 2004), affects the quality and outcomes of PD. At policy level, there are pledges to provide teachers with ongoing PD opportunities and then to link progress in the career with their engagement in and use of PD. However, the existing practices in schools hardly reflect the stated policies. Although, limited teachers avail PD opportunities mainly organized by NGOs, the trainee teachers lack any follow-up support either from the PD providers or government education officials to ensure the implementation of the newly learned ideas and skills. Government education officials occasionally visit schools, however, they scarcely evaluate teachers with regards to any innovations in their instructional practices. The responsibility of appraisal rests with the school leaders who use ACR to evaluate teachers' performance during the year. However, this tool lacks any space to evaluate teachers' engagement in PD. The outcome is kept confidential from the concerned teacher, denying any opportunity to understand the areas for improvement. There is no recognition for teachers who take the initiative on their own with regards to PD practices. It does not make a difference in the career of teachers whether they update their practices or not. Innovative behaviours are said to be supported in an environment where teachers are appraised, recognised and rewarded based on their innovations and development (Nemeržitski, Loogma, Heinla, \& Eisenschmidt, 2013; Trehan \& Paul, 2014). When the system lacks such environment, the participation of teachers in PD activities is quite predictable.

The research showed some evidence of monitoring and accountability in the private sector. In the verge of competition and owing to the pressure from parents, principals of the private schools expect innovative practices from teachers. To meet such expectations and fearing any undesirable outcome for the otherwise, teachers feel the need of learning and development driving them towards exploiting various PD opportunities. The scenario lends weight to the argument that teachers do make changes in their practices, but this happens largely in a systematic and rigorous accountability environment (Wells, 2014).

The apparently simple findings that this research produced exhibit insights resounding remarkable implications for the policy makers, PD providers and educational managers. The research 
identified that unless the system where teachers work recognises and facilitates PD, teachers are less likely to engage in or benefit from PD activities. It is argued, therefore, that consideration of system related factors should be a priority if teachers are to be afforded with effective PD opportunities (Hochberg \& Desimone, 2010). An initial step in this regard would be agreeing on standards for teachers and outcomes for PD as suggested in the accountability model of PD (Hochberg \& Desimone; 2010). A perception has developed historically in this region that anyone can be a teacher irrespective of their capacity and preparation. This perception is to be contrasted with the expert perspectives regarding the knowledge required for effective teaching, such as content knowledge, pedagogical content knowledge and curricular knowledge (Shulman, 1986).

A potential strategy to develop standards for teachers would be to utilise the already developed National Professional Standards for Teachers (Ministry of Education, 2009b). While efforts to develop existing teachers' performance to those standards or expecting existing teachers to demonstrate those standards will entail considerable challenges, introducing these standards with all the key stakeholders will serve several purposes. Firstly, it will establish the perception that teaching is a profession that requires certain practice standards. Secondly, these standards will assist teachers to reflect on their identity and to evaluate whether they possess the desired knowledge, skills and attitude required for effective teaching. Evidence suggests that in other contexts where such standards are deployed, teachers use them as a framework for professional learning (Mayer, Mitchell, Macdonald, \& Bell, 2005).

Coupled with the standards set for teachers, system-wide recognition and reward for good teaching as well as engagement in and utilisation of PD has the potential to encourage teachers to realise the importance of PD for their career and advancement in the profession. Teachers should be required to demonstrate their ongoing involvement in PD activities, generated by a sense of accountability established through new system expectations. A minimal level of engagement in some type of continuing PD within a stated time frame should be an established requirement for teachers. Merely making PD compulsory for teachers, however, would be insufficient without the addition of rewarding teachers for their involvement in PD activities (Fullan, 2014).

In order to provide teachers with rewards and incentives, the system needs to establish deliberate strategies requiring a systematic evaluation of teachers. There is an existing teacher appraisal system that can be modified to contain a weighting for teachers' involvement in PD and used to evaluate the teachers' performance for both accountability and development functions (OECD, 2013). Rather than maintaining the current practice of keeping the tool and its outcomes confidential, it would be more effective if the outcomes are shared with teachers so that they have greater clarity about areas for potential improvement. Gradually, the system should shift away from appraisal and surveillance toward support and development.

Once decisions are made on teachers' involvement and effective utilisation of PD through systematic appraisal, teachers should be provided incentives and rewards based on their performance. These rewards and incentives could be in the form of increment upgrades and considerations for promotion. Furthermore, high performing teachers may also be acknowledged through honouring them with titles, certificates and even words of appreciation. If PD is made compulsory for teachers and when there are opportunities for recognition, career advancement, growth and achievement, teachers' motivation towards PD will be enhanced (McMillan, McConnell, \& O'Sullivan, 2016). Studies suggest that many issues in education can be reduced by investing more on monitoring and accountability (Muralidharan, Das, Holla, \& Mohpal, 2016).

\section{Conclusion}

In educational literature, a seeming consensus is shown on the features of PD and efforts are made to generalise those features across contexts without considering the realities and other factors influencing PD in particular regions. This research showed that monitoring and accountability mechanisms are the most influential factors in PD of teachers. No matter how effective a PD with 
regard to its design features is, unless there is proper monitoring and accountability, teachers are less likely to benefit from those 'well-designed' programmes. The effectiveness of a PD should be evaluated based on how a programme impacts the practices of teachers and achievement of students. Since monitoring and accountability mechanisms are more likely to ensure implementation of training ideas, the focus of planners, policy makers and PD providers should be on enhancing monitoring and accountability systems. Continuing with the existing practices arguably seems a wastage of resources given that those practices have failed to show any significant impact on the practices of teachers. A substantial and timely solution suggested by the relevant stakeholders and supported by educational literature is enhancing monitoring and accountability mechanism in our schools. The prudent way would be to attend to this immediate need without wasting any further time and resources on the activities that yield no positive outcome. The sooner the better.

\section{Notes}

1 Founded and guided by His Highness the Aga Khan, the Aga Khan Development Network (AKDN) brings together a number of development agencies, institutions, and programmes that work primarily in the poorest parts of Asia and Africa.

2 Pseudonyms have been used instead of the real names of the participants.

\section{References}

Agha, A. F., Alwi, S. K. K., \& Shaiq, M.(2020). Teachers' perception of the effectiveness of teachers appraisal systems in private schools of Pakistan. New Horizons, 14(1), pp. 33-48.

Ali, T.(2011). Understanding how practices of teacher education in Pakistan compare with the popular theories and narrative of reforms of teacher education in international context. International Journal of Humanities and Social Science, 1(8), pp. 208-222.

Andrabi, T., Das, J., \& Khwaja, A. I.(2008). A dime a day: The possibilities and limits of private schooling in Pakistan. Comparative Education Review, 52(3), pp. 329-355.

Behlol, M. G., Dad, H., \& Raja, S. A.(2014). Educational policies syndrome: Teacher education programmes and teacher recruitment practices in Pakistan. Journal of Research in Social Sciences, 1(1), pp.52-66.

Bennell, P.(2004). Teacher Motivation and Incentives in Sub-Saharan Africa and Asia. Available at https://pdfs.semanticscholar.org/0009/cc7e647c18899afbbf6b19a3362591fd8b32.pdf [Accessed 15 May 2017].

Bloor, M., Frankland, J., Thomas, M. \& Robson, K. (2001). Focus Groups in Social Research. London: Sage.

Bogdan, R. C., \& Biklen, S. K.(1998). Qualitative Research in Education: An introduction to theory and methods. London: Allyn and Bacon.

Clarke, A.(2006). Qualitative interviewing: Encountering ethical issues and challenges. Nurse Researcher, 13(4), pp. 19-29.

Darling-Hammond, L.(2000). How teacher education matters. Journal of Teacher Education, 51(3), pp. 166-173.

Darling-Hammond, L.(2004). Standards, accountability, and school reform. Teachers College Record, 106(6), pp. 1047-1085.

Darling-Hammond, L.(2017). Teacher education around the world: What can we learn from international practice? European Journal of Teacher Education, 30(3), pp. 291-309.

Darling-Hammond, L., \& McLaughlin, M. W.(2011). Policies that support professional development in an era of reform. Kappan, 92(6), pp. 81-92.

Darling-Hammond, L., Wei, R. C., Andree, A., Richardson, N., \& Orphanos, S.(2009). Professional Learning in the Learning Profession: A status report on teacher development in the United States and abroad. Available at http://outlier.uchicago.edu/computerscience/OS4CS/landscapestudy/ 
resources/Darling-Hammond,\%20Wei,\%20Adnree,\%20Richardson\%20and\%20Orphanos,\%20 2009\%20\%20(1).pdf[Accessed 20 June 2019].

Dinham, S.(2007). How schools get moving and keep improving: Leadership for teacher learning, student success and school renewal. Australian Journal of Teacher Education, 51(3), pp. 263-275.

Easton, L.(2008). Powerful Designs for Professional Development. 2nd Edition. Oxford, OH: National Staff Development Council.

Fraenkel, J. R., \& Wallen, N. E.(2009). How to Design and Evaluate Research in Education he Nature of Qualitative Research (7th ed.). New York: McGraw-Hill.

Fullan, M.(1993). Why teachers must become change agents. Educational Leadership, 50(6), pp. 12-17.

Fullan, M.(2007). The New Meaning of Educational Change. New York: Teachers College Press.

Fullan, M.(2014). Leading in a Culture of Change Personal Action Guide and Workbook. Freehold, NJ: John Wiley \& Sons.

Government of Khyber Pakhtunkhwa (n.d.). Annual Statistical Report of Government Schools 20172018. Available at http://175.107.63.45/NewIMUSite/images/reports/ASC2017-18Final_new. pdf[Accessed 15 June 2018].

Guba, E. G. \& Lincoln, Y (2000). Paradigmatic controversies, contradictions, and emerging confluences In N. K. Denzin and Y. S. Lincoln (Eds.) Handbook of Qualitative Research (second edition). Thousand Oaks, CA: Sage, pp. 163-188.

Guskey, T. (2000). Evaluating Professional Development. Thousand Oaks, CA: Corwin Press.

Hargreaves, A. (2003) Teaching in the Knowledge Society: Education in the Age of Insecurity. New York: Teachers' College Press and Buckingham: Open University Press.

Hattie, J.(2003). Teachers Make a Difference, What is the Research Evidence? Available at http://research.acer.edu.au/cgi/viewcontent.cgi?article=1003\&context=research_ conference_2003[Accessed 28 March 2016].

Hochberg, E. D., \& Desimone, L. M.(2010). Professional development in the accountability context: Building capacity to achieve standards. Educational Psychologist, 45(2), pp. 89-106.

Hussain, R., \& Ali, S.(2010). Improving public school teachers in Pakistan: challenges and opportunities. Improving Schools, 13(1), pp. 70-80.

Hyun, R. J., \& Sajjad, S.(2018). Quality of teachers' performance evaluation in public and private secondary schools of Karachi, Pakistan. Pakistan Journal of Education, 35(2), pp. 157-174.

Khan, G., Khan, A., Hussain, S., \& Shaheen, N.(2017). Teacher evaluation: Global perspectives and lessons for Pakistan. Dialogue (Pakistan), 12(3), pp. 1-18.

Khan, H. M. A., Chandio, J. H., \& Farooqi, M. T. K.(2014). Comparison of performance appraisal system in public and private schools. Pakistan Journal of Commerce and Social Sciences (PJCSS), 8(1), pp. 278-288.

Khan, M.(2015). Building capacity or provoking fear: Early childhood teachers' appraisal for professional development. Pakistan Journal of Psychological Research, 30(2), pp. 189-205.

Kinnucan-Welsch, K., Rosemary, C. A., \& Grogan, P. R.(2006). Accountability by design in literacy professional development. The Reading Teacher, 59(5), pp. 426-435.

Lange, S.(2014). Learner orientation through professional development of teachers? Empirical results from cascade training in Anglophone Cameroon. Compare: A Journal of Comparative and International Education, 44(4), pp. 587-612.

Lohman, M. C.(2000). Environmental inhibitors to informal learning in the workplace: A case study of public school teachers. Adult Education Quarterly, 50(2), pp. 83-101.

Mayer, D., Mitchell, J., Macdonald, D., \& Bell, R.(2005). Professional standards for teachers: a case study of rofessional learning. Asia-Pacific Journal of Teacher Education, 33(2), pp. 159-179.

Mbiti, I. M.(2016). The Need for Accountability in Education in Developing Countries. Journal of Economic Perspectives, 30(3), pp. 109-132. 
McMillan, D. J., McConnell, B., \& O’Sullivan, H.(2016). Continuing professional development-why bother? Perceptions and motivations of teachers in Ireland. Professional Development in Education, 42(1), pp. 150-167.

Ministry of Education.(2009a). National Education Policy. Islamabad: Government of Pakistan.

Ministry of Education.(2009b). National Professional Standards for Teachers of Pakistan. Policy and Planning Wing, Government of Pakistan. Islamabad: Government of Pakistan

Mohammed, R. F., \& Harlech-Jones, B.(2008). The fault is in ourselves: looking at 'failures in implementation'. Compare: A Journal of Comparative and International Education, 38(1), pp. 39-51.

Muralidharan, K., Das, J., Holla, A., \& Mohpal, A.(2016). The fiscal cost of weak governance: Evidence from teacher absence in India. Journal of Public Economics, 145, pp. 116-135.

Nadeem, M., Arif, S., \& Asghar, M. Z.(2019). Effectiveness of the teacher appraisal system in public higher secondary schools of Punjab (Pakistan). Global Regional Review, 4(1), pp. 194-208.

National Education Management Information System (2017). Pakistan Education Statistics 20152016: Ministry of Education and Professional Training. Islamabad: Government of Pakistan.

Nawab, A.(2017). What difference could in-service training make? Insights from a public school of Pakistan. Teacher Development, 21(1), pp. 142-159.

Nemeržitski, S., Loogma, K., Heinla, E., \& Eisenschmidt, E.(2013). Constructing model of teachers' innovative behaviour in school environment. Teachers and Teaching, 19(4), pp. 398-418.

OECD (2013). Teachers for the 21st Century: Using Evaluation to Improve Teaching. Available at http://dx.doi.org/10.1787/9789264193864-en[Accessed 21 March 2017].

Patton, M. Q.(2002). Qualitative Research and Evaluation Methods: Thousand Oaks, CA: Sage Publications.

Ramatlapana, K. A. (2009). Provision of in-service training of mathematics and science teachers in Botswana: teachers' perspectives. Journal of Mathematics Teacher Education, 12(2), pp. 153-159.

Reeves, D.(2005). Putting it all together: Standards, assessment, and accountability in successful professional learning communities. In R. DuFour, R. Eaker and R. DuFour (Eds.) On Common Ground: The power of professional learning communities. Bloomington, IN: Solution Tree Press, pp. 45-63.

Rizvi, M., \& Elliott, B.(2007). Enhancing and sustaining teacher professionalism in Pakistan. Teachers and Teaching, 13(1), pp. 5-19.

Rubin, H. J., \& Rubin, I. S.(2011). Qualitative interviewing: The art of hearing data. Thousand Oaks, CA: Sage.

Shulman, L. S.(1986). Those who understand: Knowledge growth in teaching. Educational Researcher, 15(2), pp. 4-14.

Siddiqui, S.(2016). Education Policies in Pakistan: Politics, Projections, and Practices. Karachi: Oxford University Press.

Smith, A.(2014). Contemporary challenges for education in conflict affected countries. Journal of International and Comparative Education, 3(1), pp. 113-125.

Trehan, R., \& Paul, J.(2014). Determinants of attitude of teachers-factor analysis and strategies for success. Competitiveness Review, 24(1), pp. 5-19.

UNESCO.(2011). World Data on Education. Available at http://www.ibe.unesco.org/sites/default/ files/Pakistan.pdf[Accessed 19 July 2015].

USAID.(2006). Situation analysis of Teacher Education: Towards a strategic framework for teacher education and professional development, Pakistan. Available at https://eric. ed.gov/?id=ED497052[Accessed 18 June 2014].

Wells, M.(2014). Elements of effective and sustainable professional learning. Professional Development in Education, 40(3), pp. 488-504.

World Bank.(2004). World Development Report 2004: Making services workfor poor people. Available at https://openknowledge.worldbank.org/handle/10986/5986[Accessed 08 January 2015]. 
Monitoring and Accountability in Professional Development of Teachers in Rural Pakistan

Yi, P., \& Kim, H. J.(2019). Exploring the relationship between external and internal accountability in education: A cross-country analysis with multi-level structural equation modeling. International Journal of Educational Development, 65, pp. 1-9. 
